\title{
The Effect of Using Online Collaborative Tasks on Incidental Vocabulary Learning of Impulsive vs. Reflective Iranian EFL Learners
}

\author{
Khalil Motallebzadeh \\ English Department, Islamic Azad University, Torbat-e Heydarieh Branch, Iran \\ E-mail: k.motalleb@iautorbat.ac.ir \\ Farideh Samadi (Corresponding author) \\ English Department, Islamic Azad University, Torbat-e Heydarieh Branch, Iran \\ E-mail: samadi.farideh.86@gmail.com
}

Received: 10-04-2017

Accepted: 06-06-2017

Advance Access Published: September 2017

Published: 01-11-2017

doi:10.7575/aiac.ijalel.v.6n.6p. 127

URL: http://dx.doi.org/10.7575/aiac.ijalel.v.6n.6p.127

\begin{abstract}
Incidental vocabulary learning is one of the most significant sources of learning vocabulary for language learners (Laufer \& Hulstjin, 2001). This study endeavored to investigate the effect of using online collaborative tasks on incidental vocabulary learning of impulsive vs. reflective Iranian EFL learners. To this end, Nelson vocabulary proficiency test was administered to 100 Iranian EFL learners as the homogeneity test and the pretest. Using random sampling procedure, 75 learners were selected as the main participants for this study. Kember, McKay, Sinclair and Wong (2008) reflective thinking questionnaire was administered to these learners, based on which they were distinguished based on their cognitive thinking styles, i.e., impulsivity and reflectivity. The participants were homogenously distributed into 3 main groups (impulsive experimental group, reflective experimental group, and the control group). All participants went through 4 weeks of treatment. Experimental groups were conducted using Telegram software and the control group was conducted in a classroom. The results of t-test after 4 weeks of treatment revealed that reflective learners benefited from online collaborative groups with regard to incidental vocabulary learning. The findings of the study are discussed in light of previous research.
\end{abstract}

Keywords: Online collaborative tasks, incidental vocabulary learning, impulsive learners, reflective learners

\section{Introduction}

Vocabulary is one of the most intensively studied language subskills. Not only is it a core component of language learning processes (Wilkins, 1972), but also its role in reading comprehension (Macalister, 2010), writing performance (Lee, 2003) and English for specific purposes (ESP) (Dudley-Evans \& St John, 1998) has already been acknowledged.

The intensive research on vocabulary learning has lead scholars to view vocabulary of two types: a) intentional vocabulary learning as what is deliberately taught to the students and b) incidental vocabulary learning as a by-product of being involved in a language task such as speaking which is non-vocabulary (Laufer \& Hulstjin, 2001). While intentional vocabulary learning was stressed in many language learning methodologies, of interest to many recent researchers has been incidental vocabulary learning. The reason may be that more recent research findings have perpetuated the significance of this type of vocabulary learning as a useful tool to learn new vocabularies (i.e, Richards \& Schmidt, 2002; Brown, Waring \& Donkaewbua, 2008). For example, Brown, Waring and Donkaewbua (2008) stated that incidental vocabulary learning is a more practical vocabulary learning method for EFL learners in lower proficiency levels and can be gained through reading.

In addition, recent studies in English as a foreign language contexts (EFL) have revealed that vocabulary learning has interactions with language learners' learning styles. Isazadeh, Makui and Ansarian (2016) reported on the intricacies between vocabulary learning and extraversion learning styles while using authentic and instructional video materials. In another study (Mesgarani, 2016), believed that impulsivity and reflectivity can have correlations with vocabulary intake while using output-based instruction. The focus accorded to vocabulary learning and language learners' learning styles motivated the researcher to conduct the study on the effect of online collaborative tasks on incidental vocabulary learning of Iranian impulsive vs. reflective EFL learners.

\subsection{Statement of the problem}

Incidental vocabulary learning, though a significant type of vocabulary as noted by (Huckin \& Coady, 1999) has been taken for granted in the EFL context of Iran. Explicit instruction of vocabulary is usually confined to the vocabulary 
introduced in the language books. Thus, language learners do not have the chance to learn vocabulary incidentally. This may result in insufficient knowledge of vocabulary among EFL learners.

In addition, although the wealth of recent literature shows that computer assisted language learning (CALL) can positively affect learning the foreign language, most language classes are deprived from online language tasks. In the same vein, collaborative tasks in classes are conducted traditionally and without possible facilitation of online atmospheres.

Such insufficiencies may result in inadequate knowledge of vocabulary among Iranian EFL learners which, in turn, affects their speaking, writing and many other areas of language.

\subsection{Purpose of the Study}

This study aimed at increasing Iranian EFL learners' knowledge of vocabulary learning. To this end, the researcher endeavored to find out how online collaborative tasks may foster learning of incidental vocabulary. Moreover, following the procedure presented, this study can provide Iranian language teachers with guidelines to implement online collaborative tasks in language classes; believing that it may result in providing language learners to produce the language by getting them involved in it.

\subsection{Research Questions}

The following research questions were proposed for this study:

Q1: Do online collaborative tasks have any effect on incidental vocabulary learning of impulsive Iranian EFL learners?

Q2: Do online collaborative tasks have any effect on incidental vocabulary learning of reflective Iranian EFL learners?

Q3: If the answers to research Questions 1 and 2 are 'yes', which of the reflective or impulsive Iranian EFL leaners benefit more from online collaborative tasks in terms of incidental vocabulary learning?

\subsection{Research Hypotheses}

According to the research questions, the following research hypotheses were formed for this study:

H01: Online collaborative tasks do not have any effect on incidental vocabulary learning of impulsive Iranian EFL learners.

H02: Online collaborative tasks do not have any effect on incidental vocabulary learning of reflective Iranian EFL learners.

H3: The effect of online collaborative tasks on incidental vocabulary learning of Iranian impulsive and reflective EFL learners will not be equal.

\subsection{Limitations and Delimitations}

Notwithstanding the fact that EFL learners' learning styles vary greatly and are not confined to impulsive and reflective EFL learning styles, due to the limitations imposed on the study with regard to the number of participants, the researcher decided to focus only on the aforementioned learning styles, i.e, impulsivity and reflectivity.

Although all participants in this study were adult EFL learners, the results of the study cannot be interpreted with regard to age. In addition, since the participants' for this study were be of mixed gender, gender cannot be considered as a moderator variable. Other factors such as educational and cultural background were not sought as well.

Finally, investigating the effect of online collaborative tasks on EFL learners' vocabulary learning considering impulsive and reflective learning styles is a novel study. Therefore, more research is required to prove the external validity of the findings.

\section{Review of the Literature}

\subsection{Theoretical Background}

Online collaborative learning as stated by Gale (2003) emphasized learning through using different sources; a studentcentered activity which is conducted on the web. The key feature of this type of learning is interaction among the members of the group (Razon et al., 2012). The pinnacle of this type of learning can be traced back to works of Vygotsky (1978) with regard to social constructivism. In general, Not only does collaborative learning require social interactions (Zimmerman, 1989), but also use of cognitive, social and motivational processes (pintrich, 2000). Vygotsky (1978) social constructivism is regarded as the main theoretical framework in this study.

\subsubsection{Collaboration and Language Learning}

Storch (2005) and Kim (2008) put emphasis on the effect of collaborative leaning by positing that it enhanced students' critical thinking abilities. Many studies have supported the positive effect on collaboration on language learning. Kennedy and Miceli (2013), for example, find collaboration an effective factor in EFL learners' perception of wikis and sense of integration in a community.

Collaboration is often regarded to have a positive effect on learners' social aspect (Gardner, 1985).It helps learners to tolerate the rigorous procedure of learning and to accomplish a goal (Dörnyei, 1998). In addition, Razon et al. (2012) considers collaboration to be a vital factor in EFL/ESL learners' success by motivating them to win a prize or achieve a goal. 


\subsubsection{Collaboration and Online Tasks}

In general it is assumed that there is a relationship between the amount of time students spent on the net learning a novel issue and their self-regulation ability (Lee \& Tsai, 2011). They also believe that the amount of time students investigate online in a given activity has a direct relationship with their attitude towards technology. Such attitudes (behaviors in a broader sense) affect students' willingness to process the information and ideas presented by other people (Tsai \& Tsai, 2013) which can be an important factor in online collaborative tasks. However, it is believed that online collaboration can reduce the cognitive pressure placed on one's working memory and help individuals analyze problem at a faster pace (Storch, 2005). As a result and as stated by Kirschner et al. (2009) in-depth learning occurs by activating students schemata.

However, many of the studies carried out in order to investigate the effect of online collaborative tasks have had their focus on qualitative factors such as students' motivation and not the factors that affect this process. As a result, this study is considered as a response to the emerging need for investigating the constructs affecting online collaboration with regard to incidental vocabulary learning

\subsubsection{Learning Styles and Language Learning}

A significant and recent concept in EFL education has been EFL learners' learning styles and the importance of attending to this issue in order to conduct research which can yield more accurate results. Learning style refers to learners preferred way of learning (Wang, 2008). Learning styles play a crucial role within the lives of learners. Once students acknowledge their own learning type, they'll be able to integrate it into their learning method (Folse, 2008). Another advantage of distinguishing learners' learning style is that it assists language learners in more effective comprehension. The more the learners know of their learning styles, the more they will learn (Biggs, 2001).

Matching is particularly necessary in order to cope with poor learners as they simply become demotivated at early stages of learning. In alternative occasions, mismatching can be convenient in order to facilitate learners' expertise in using new strategies of learning and accommodate other ways of thinking. However, mismatching ought to be treated with cautiousness because it could cause learners' dropouts (Tuan, 2011). This fact, will justify the inordinateness of analysis meted out with relation to learning styles and homogeneity of language categories.

Two significant cognitive learning styles are impulsivity and reflectivity. Impulsivity refers to the degree to which learners make hurried choices and guess the answer to questions without properly reflecting on the issue and their understanding. Reflectivity, on the other hand, refers to language learners' ability to reflect on questions and think about them prior to answering them (Folse, 2008).

\subsection{Empirical Background}

Some scholars have conducted studies to observe the effects of collaboration, online sources and combination of both on learning the second language. For example, Kessler, Bikowski, \& Boggs (2012) posit that in an online environment, students are more likely to help each other (in terms of strategy use and linguistic knowledge). Although the focus of their study was on the writing skills, implications of their study may be applicable to learning vocabulary.

Kennedy and Miceli (2013) designed a correlational study to understand whether there are any relationship between students' perception of the wikis and positive perception with the sense of community they feel on the net. The findings of their study (by considering 173 subjects) proved that there are significant relationships between the above mentioned issues and that the world wide web can help students have a more tangible sense of community.

In a different study, Yang (2011) investigated the effect of social tools on EFL learners' sense of motivation and their enthusiasm for learning the new language. The findings of the study carried out by Yang (2011), proved that social web tools can greatly affect students motivation.

Yet, in another study, Ma and Kelly (2006) proved that there are relationships between the time spent by the student to accomplish a task and the learning outcomes and students evaluation of the importance of the task. In order to carry out the study, they observed student actions during the task, considered the time spent by them on tasks and made comparisons between these issues and the students' scores on the task as their achievement.

Finally Lee and Tsai (2011), by carrying out a correlation study, concluded that there are significant relationship between the time students spend on the net and their learning as they find out the quality of learning, self-regulation, and collaborative learning among these students increases with the increase in time spend on the net, especially in case the students are involved in an online task such as those in online forums.

\section{Methodology}

\subsection{Design of the study}

This study had a true-experimental design due to random sampling procedure used in selecting the participants in the study (see Mackey and Gass, 2015). The main independent variable in the study was the effect of online collaborative tasks and the main dependent variable was incidental vocabulary learning of the learners. As the results of the study are based on the observed data, and as stated by Creswell (2013) positivism is the more suitable philosophical paradigm for the study. 
In order to determine the number of required participants for the study, power analysis was conducted. Considering the results of the analysis, 100 Iranian EFL learners were given Nelson vocabulary test as a proficiency test and the pretest. By choosing the participants within the range of +/_1SD, 75 EFL learners were chosen as the participants for the study. After that, the participants were given Kember et al.'s (2008) reflective thinking questionnaire to be homogenized into reflective and impulsive learners. Based on the result of the questionnaire, 25 more reflective EFL participants formed experimental Group I, 25 more impulsive EFL participants formed experimental Group II, and 25 participants with mixed learning styles formed the control group. Table 1 reveals he demographics of the participants.

Table 1. Participants Demographic Data

\begin{tabular}{lcllll}
\hline Group & $\mathrm{N}$ & Gender & $\begin{array}{l}\text { Experience in Learning } \\
\text { English }\end{array}$ & Religion & Age \\
\hline $\begin{array}{l}\text { Reflective- } \\
\text { Experimental }\end{array}$ & 25 & Mixed & Between 1 to 2 years & Islam & $18-22$ \\
\hline $\begin{array}{l}\text { Impulsive- } \\
\text { Experimental }\end{array}$ & 25 & Mixed & $\begin{array}{l}\text { Between 1 year to 20 } \\
\text { months }\end{array}$ & Islam & $17-31$ \\
\hline Control-Mixed & 25 & Mxed & $\begin{array}{l}\text { Between 14 months to } \\
22 \text { months }\end{array}$ & Islam & $19-27$ \\
\hline
\end{tabular}

\subsection{Procedure}

This study was conducted in 22 sessions over the period of 2 months. The participants in the experimental groups joined a group on telegram channel. A photo of the conversation was shown to the participants in order to activate the participants schema by eliciting information about the theme of the conversation (questions and answers were either typed or sent through audio files). Next, the participants were presented with the conversations audio file and were asked to listen to the file in order to answer the questions. The teacher also asked questions regarding the conversations to make sure the students had understood the conversation. Finally, the students were asked to practice making a new conversation by taking roles in the conversation and by suggesting sentences to continue the conversation. Meanwhile, the teacher took note of the incidental vocabulary exchange between the students.

A researcher-made posttest was designed by the researcher based on the collection of incidental vocabularies and was administered after the treatment to both groups.

Same conversations were taught to the participants in the control group in a classroom setting. The conversations were practiced as mentioned in the interchange series and incidental vocabularies (words other than the ones mentioned in the book) were considered as the target words to be assessed in the posttest.

\section{Data Analysis}

In the first phase of the data Analysis assumption of normal distribution of scores was checked for both pretest and posttest scores as a prerequisite of a parametric study. As revealed in Table 2, normal distribution was observed in all sets of scores.

Table 2. Test of Normality, All Tests

\begin{tabular}{lcccccc}
\hline & & $\mathrm{N}$ & \multicolumn{2}{c}{ Skewness } & \multicolumn{2}{c}{ Kurtosis } \\
\cline { 3 - 7 } & & Statistic & Statistic & Std. Error & Statistic & Std. Error \\
\hline Nelson Vocabulary Proficiency Test & 75 & .324 & .198 & .396 & .198 \\
\hline \multirow{2}{*}{$\begin{array}{l}\text { Pretest of } \\
\text { Vocabulary }\end{array}$} & Control & 25 & .078 & .464 & -.337 & .356 \\
& Experimental 1 & 25 & .47 & .545 & .334 & .354 \\
\cline { 2 - 7 } & Experimental 2 & 25 & .043 & .464 & .675 & .211 \\
\hline \multirow{2}{*}{$\begin{array}{l}\text { Posttest of } \\
\text { Vocabulary }\end{array}$} & Control & 25 & .401 & .464 & .398 & .937 \\
\cline { 2 - 7 } & Experimental 1 & 25 & .653 & .765 & .567 & .821 \\
\hline
\end{tabular}

Having distributed the learners into reflective and impulsive EFL learners based on the results of the Kember et al. (2008) reflective thinking questionnaire, the ANOVA test was carried out. According to Table 3, one-way ANOVA test, the $F$ value $\left(F_{3,96}=0.667, p=0.365\right)$ indicated that there was not a statistically significant difference among the groups and they were homogenous in terms of vocabulary knowledge. 
Table 3. ANOVA, Pretest of Vocabulary

\begin{tabular}{lccccc}
\hline & Sum of Squares & df & Mean Square & F & Sig. \\
\hline Between Groups & 12.840 & 3 & 3.987 & .667 & .365 \\
\hline Within Groups & 487.350 & 96 & 5.467 & & \\
\hline Total & 598.110 & 99 & & & \\
\hline
\end{tabular}

The reliability of Nelson test was gauged using Crombach Alpha formula $(\alpha=.78)$.

\subsection{The First Research Question}

Do online collaborative tasks have any effect on incidental vocabulary learning among impulsive Iranian EFL learners?

In order to answer the first research question, the results of the control group and the impulsive experimental group were compared using independent samples t-test.

Table 4. Independent Samples t-test; Impulsive Learners and the Comparison Group

\section{Levene's Tes \\ $t$ for Equality \\ of Variances}

t-test for Equality of Means

\begin{tabular}{|c|c|c|c|c|}
\hline \multirow[t]{2}{*}{$\begin{array}{l}\text { F Sig. } \\
\text { Difference }\end{array}$} & $\mathrm{t}$ & \multirow[t]{2}{*}{ df $\underset{\text { (2-tailed) }}{\text { Sig. }}$} & \multirow[t]{2}{*}{$\begin{array}{l}\text { Mean Std. Error } \\
\text { Difference }\end{array}$} & $\begin{array}{c}95 \% \text { Confidence } \\
\text { Interval of the } \\
\text { Difference }\end{array}$ \\
\hline & & & & Lower Upper \\
\hline
\end{tabular}

Male_female_pretest Equa

1 variances

assumed

$\begin{array}{llllllll}.311 & .415 & .780 & 49 & .654 & .5433 & .7984 & 2.5342\end{array}$

Equal

variances

not assumed

The results of the independent $\mathrm{t}$-test $(\mathrm{t}(49)=.780, \mathrm{p}=.656, \mathrm{r}=.798$ represents a week Effect size. Thus, the difference between the groups was not significant. As a result, the first null hypothesis was supported.

According to Levene's $\mathrm{F}=0.311, \mathrm{p}=.415$, Equal variances was assumed.

\subsection{The second Research Question}

Do online collaborative tasks have any effect on incidental vocabulary learning among reflective Iranian EFL learners?

Independent samples t-test was run between the control group and the reflective experimental group in order to seek the answer to research question 2.

Independent samples t-test results (Table 5$)$ represents that scores were significantly higher for experimental groups $(M$ $=23.18, S D=2.985)$ than for comparison groups $(M=16.18, S D=2.707), \mathrm{t}_{(98)}=3.825, p<.0005$. Then the second null hypothesis $\left(\mathrm{H}_{02}\right)$ was rejected. According to Levene's $\mathrm{F}=.798, p=.358$, "Equal variances assumed" was reported.

Table 5. Independent Samples t-test; Posttest of Reflective Experimental Group and the Control Group

Levene's Test for

Equality of

Variances t-test for Equality of Means

95\% Confidence

Interval of the

Sig. Mean Std. Error Difference

$\mathrm{F} \quad$ Sig. $\mathrm{t}$ df (2-tailed) Difference Difference

\begin{tabular}{|c|c|c|c|c|c|c|c|c|c|c|}
\hline Vocabular & $\begin{array}{l}\text { Equal } \\
\text { variances } \\
\text { assumed }\end{array}$ & .798 & .358 & 3.825 & 98 & .000 & 5.000 & .570 & 1.049 & 3.311 \\
\hline $\begin{array}{l}\mathrm{y} \\
\text { Post Test }\end{array}$ & $\begin{array}{l}\text { Equal } \\
\text { variances }\end{array}$ & & & 3825 & 07073 & 000 & 5000 & 570 & 1040 & 3311 \\
\hline
\end{tabular}


In addition as both null hypotheses should have been rejected as the presumption for the third research question and as research hypothesis 1 was supported, the answer to the last research hypothesis was not investigated.

\subsection{Analysis of the posttest}

A number of tests were conducted with regard to the researcher-made posttest to investigate its suitability for this study. as the main issue with regard to construct validity of a test is designing the test items in such a way that represent what is to be tested (Hatch and Frahady, 1982), and as the incidental vocabularies were collected throughout the courses and used in the test, the main issue with regard to construct validity of the tests is answered.

Item analysis was run to find out who proper the questions in the test are., item analysis showed that the item facility of the test's items was between 0.5 and 0.8 and discrimination indices were between 0.25 and $0.5,(0.5<I F<0.8$ and 0.25 $<D I<0.5)$ which are in the acceptable ranges. Then, the test items are not too easy or too hard and the test has the power to distinguish between different test takers.

\section{Discussion}

The findings of the study are in some cases congruent with previous studies; at the same time, contrasts are seen with previous findings which are discussed in this section. Yang (2011) asserted that social tools enhance students' motivation to learn; therefore, learning is fostered among them. In addition, Linden and Renshaw (2001) noted that creating the opportunity for the students to interact in form of dialogues enables them to learn. They also asserted that prompts and online posts by instructors help interactions among the students to occur more naturally. These studies have had their focus on collaborative learning and mostly online environments; however, language learners learning styles have not been taken into consideration. This may justify why the findings of this study partially accord with these studies. In the current study, it was observed that online collaborative tasks can have positive effect on vocabulary learning of reflective Iranian EFL learners; however, this effect was not observed regarding the impulsive learners.

Hobaugh (1997) asserts that the social dynamics among the group members in online environment can contribute to the success or failure of education delivered in such atmospheres. One of the main dynamics of online interactions, as stated by Gunawardena (1995), is text-based interaction. Text-based interaction can make concentration of the dialogues difficult for some learners. In general, impulsive learners have less concentration and tend to make gambling guesses at the answers (Wang, Wang, \& Huang, 2008). This may justify why the online collaborative tasks had effect on incidental vocabulary learning of reflective language learners and not the impulsive ones.

Joe (1995) believed that text-based tasks can affect learning of incidental vocabulary by proving visual exposure to the words. Laufer (1992) also asserted that reading is the main source of vocabulary learning. The current study also revealed that online collaborative groups have significant effect on incidental vocabulary learning of the reflective learners which may be due to the fact that the words are observed in form of texts and are read in the online environment.

Vocabulary learning and learning styles have also been subject of recent investigations in the field. Ellis (2004) believed that the effect of learning styles on language education is not an established effect and may be different in various settings. Makui, Isazadeh and Ansarian (2016) who conducted a study with regard to incidental vocabulary learning of introvert and extrovert language learners, believed that learning incidental vocabulary through video materials is not different between introvert and extrovert learners also the effect was observed in both groups. Such conclusion help interpreting the results of this study easier, as they shed light on two main facts: a) learning styles do not always show interactions with learning vocabulary, b) the effect, if observed, may be tentative. This can, in turn, justify why reflective learners benefited from incidental vocabulary learning in online collaborative groups while impulsive learners did not.

\section{Conclusion}

This study aimed to gauge the effect on online collaborative tasks on incidental collaborative learning of EFL learners in order to foster learning of incidental vocabulary. The results of 4 weeks of treatment in an online atmosphere and comparison of the results with the control group revealed that only reflective Iranian EFL learners benefit from online collaborative tasks, and the effect of this mode of teaching on impulsive learners was not statistically significant. The results could be beneficial to language teachers who wish to know about the effect of online collaborative tasks on learning incidental vocabulary. In addition, syllabus designers who implement the educational goals benefit from this study and design more effective syllables in terms of online collaborative activities. Policy makers can also benefit from the findings of this study, as the findings of the study reveal that there may be no need to match language classes based on language learners' impulsive and reflective learning styles.

\section{References}

Brown, R., Waring, R., \& Donkaewbua, S. (2008). Incidental vocabulary acquisition from reading, reading-whilelistening, and listening to stories. Reading in a foreign language, 20(2), 136.

Creswell, J. W. (2013). Research design: Qualitative, quantitative, and mixed methods approaches. Sage publications.

Dörnyei, Z. (1998). Motivation in second and foreign language learning. Language Teaching, 31, 117-135.

Dudley-Evans, T., \& St John, M. J. (1998). Developments in English for specific purposes: A multi-disciplinary approach. Cambridge university press. 
Ellis, R. (2004). 21 Individual differences in second language learning. The handbook of applied linguistics, 525.

Folse, K. S. (2008). Six vocabulary activities for the English language classroom. English Teaching Forum, 46(3), 12.

Gardner, R. C. (1985). Social psychology and second language learning. The Role of attitudes and motivation. London, UK: Edward Arnold.

Gunawardena, C. N. (1995). Social presence theory and implications for interaction and collaborative learning in computer conferences. International journal of educational telecommunications, 1(2/3), 147-166.

Hobaugh, C. F. (1997). Interactive strategies for collaborative learning. Document Resume, 120.

Huckin, T., \& Coady, J. (1999). Incidental vocabulary acquisition in a second language. Studies in second language acquisition, 21(02), 181-193.

Hulstijn, J. H. (1992). Retention of inferred and given word meanings: Experiments in incidental vocabulary learning. In Vocabulary and applied linguistics (pp. 113-125). Palgrave Macmillan UK.

Isazadeh, P., Makui, S. M. Z., \& Ansarian, L. (2016). Effect of Instructional vs. Authentic Video Materials on Introvert and Extrovert Iranian EFL Learners' Vocabulary Learning. International Journal of Education and Literacy Studies, 4(4), 1-10.

Joe, A. (1995). Text-based tasks and incidental vocabulary learning. Second Language Research, 11(2), 149-158.

Kember, D., McKay, J., Sinclair, K., \& Wong, F. K. Y. (2008). A four-category scheme for coding and assessing the level of reflection in written work. Assessment \& Evaluation in Higher Education, 33(4), 369-379.

Kennedy, C., \& Miceli, T. (2013). In piazza online: exploring the use of wikis with beginner foreign language learners. Computer Assisted Language Learning, 26(5), 389-411.

Kessler, G., Bikowski, D., \& Boggs, J. (2012). Collaborative writing among second language learners in academic webbased projects. Language Learning \& Technology, 16(1), 91-109.

Kim, Y. (2008). The contribution of collaborative and individual tasks to the acquisition of L2 vocabulary. The Modern Language Journal, 92(1), 114-130.

Kirschner, F., Paas, F., \& Kirschner, P. A. (2009). Individual and group-based learning from complex cognitive tasks: Effects on retention and transfer efficiency. Computers in Human Behavior, 25, 306-314.

Laufer, B., \& Hulstijn, J. (2001). Incidental vocabulary acquisition in a second language: The construct of task-induced involvement. Applied linguistics, 22(1), 1-26.

Lee, S. H. (2003). ESL learners' vocabulary use in writing and the effects of explicit vocabulary instruction. System, 31(4), 537-561.

Lee, S. W. Y., \& Tsai, C. C. (2011). Students' perceptions of collaboration, self-regulated learning, and information seeking in the context of Internet-based learning and traditional learning. Computers in Human Behavior, 27, $905-914$.

Linden, J. V. D., \& Renshaw, P. (2001). Dialogic Learning. Dordrecht: Kluwer Academic Publication

Macalister, J. (2010). Speed reading courses and their effect on reading authentic texts: A preliminary investigation. Reading in a Foreign Language, 22(1), 104.

Mackey, A., \& Gass, S. M. (2015). Second language research: Methodology and design. Routledge.

Mesgarani, M. (2016). The effect of input-based instruction vs. output-based instruction on vocabulary learning of impulsive vs. reflective Iranian EFL learners. (Unpublished Master's thesis) Payame Noor University, I.R. of Iran.

Pintrich, P. R. (2000). Multiple goals, multiple pathways: The role of goal orientation in learning and achievement. Journal of educational psychology, 92(3), 544.

Razon, S., Turner, J., Johnson, T. E., Arsal, G., \& Tenenbaum, G. (2012). Effects of a collaborative annotation method on students' learning and learning-related motivation and affect. Computers in Human Behavior, 28(2), 350-359.

Richards, J. C., \& Schmidt, R. (2002). Longman dictionary of applied linguistics and language teaching. Harlow, UK: Longman.

Storch, N. (2005). Collaborative writing: Product, process, and students' reflections. Journal of second language writing, 14(3), 153-173.

Tsai, P. S., \& Tsai, C. C. (2013). College students' experience of online argumentation: Conceptions, approaches and the conditions of using question prompts. Internet and Higher Education, 17, 38-47.

Vygotsky, L. S. (1978). Mind in society: The development of higher mental process.

Wang M. (2008). Learning styles and English teaching. US-China Foreign Language, 6, 30.

Wang, T. I., Wang, K. T., \& Huang, Y. M. (2008). Using a style-based ant colony system for adaptive learning. Expert Systems with applications, 34(4), 2449-2464.

Wilkins, D. A. (1972). Linguistics in language teaching. E. Arnold,

Yang, Y. F. (2011). Engaging students in an online situated language learning environment. Computer Assisted Language Learning, 24(2), 181-198.

Zimmerman, B. J. (1989). A social cognitive view of self-regulated academic learning. Journal of educational psychology, 81(3), 329-339. 